\title{
Pemenuhan Nutrisi Dan Alternatif Penghasilan Melalui Produk Olahan Ikan Bagi Masyarakat Penangkap Ikan Kelurahan Oesapa Kecamatan Kelapa Lima Kota Kupang
}

\author{
Muntasir $^{1}$., Pius Weraman ${ }^{1}$, Mustakin Sahdan ${ }^{2}$, Sri Prilmayanti A ${ }^{3}$., Nadra Aga Iryani ${ }^{3}$ \\ ${ }^{1}$ Staf Pengajar Program Studi Ilmu Kesehatan Masyarakat, Pascasarjana. \\ Universitas Nusa Cendana, Kupang, NTT. Jl. Adisucipto. Penfui. Kupang. NTT. 85000 \\ ${ }^{2}$ Staf Pengajar Program Studi Ilmu Kesehatan Masyarakat, Universitas Nusa Cendana, \\ Kupang, NTT. Jl. Adisucipto. Penfui. Kupang. NTT. 85000 \\ ${ }^{3}$ Narasumber UMKM Aisyah Kupang, Indonesia
}

Email : muntasir@staf.undana.ac.id, munbasrypps@yahoo.com

\begin{abstract}
Abstrak - Ikan laut hasil tangkapan nelayan yang melimpah di provinsi Nusa Tengara Timur menjadi salah satu hasil laut yang tiada habis utamanya bagi kelompok pekerja laut untuk dikelola dan didayagunakan menghasilkan nilai barang yang bernilai jual besar sehingga dapat memberikan nilai tambah pendapatan dan peningkatan ekonomi kelompok pekerja laut khususnya kelompok penangkap ikan utamanya nelayan dan keluarganya. Setiap harinya nelayan menjual ikan hasil tangkapan baik secara tradisional maupun dengan penggunaan mesin dan teknologi pada konsumen kedua dalam volume yang besar dan berbagai ragam jenis ikan. adakalanya, ikan yang dipasarkan itu terjual semuanya habis pada konsumen kedua, akibatnya harus disimpan atau diawetkan dalam bentuk lain yang dapat bertahan waktu lama seperti dibuat menjadi ikan asin atau ikan yang dikeringkan. Cara lain yang ditempuh adalah mengolah ikan tangkapan pekerja laut itu menjadi produk lain yang dapat dijual dan tahan lama dalam bentuk diversifikasi produk. Program kemitraan ini diharapkan menjadi alternatif pemenuhan nutrisi keluarga terutama protein hewani yang menarik bagi ibu rumah tangga dan keluarga nelayan. Juga meningkatkan nilai tambah, pengetahuan, penggunaan dan pengolahan sumber protein hewani yang dapat meningkatkan nilai gizi, tekstur, olahan dan produk sebagai bentuk penerapan ipteks perguruan tinggi, produk yang dihasilkan bisa menjadi salah satu bentuk usaha untuk meningkatkan pendapatan keluarga nelayan sehingga masyarakat pekerja laut dapat terbantukan dalam persoalan ekonomi.
\end{abstract}

Kata kunci : Nutrisi keluarga, Olahan Ikan, Nelayan Oesapa Kupang

Abstract - The sea fish caught by fishermen which are abundant in the province of East Nusa Tenggara have become one of the endless marine products, especially for groups of marine workers to be managed and utilized to produce value of goods that are of great selling value so that they can provide added value in income and increase the economy of marine workers, especially groups. the main catchers are fishermen and their families. Every day fishermen sell their catch fish both traditionally and with the use of machines and technology to second consumers in large volumes and with various types of fish. occasionally, the marketed fish is completely sold out to a second consumer, as a result it has to be stored or preserved in other forms that can long time such as being made into salted fish or dried fish. Another method taken is processing the fish caught by sea workers into other products that can be sold and are durable in the form of product diversification. This partnership program is expected to be an alternative fulfillment of family nutrition, especially animal protein, which is attractive to housewives and fishing families. Also increasing the added value, knowledge, use and processing of animal protein sources which can increase the nutritional value, texture, processing and products as a form application of university for science and technology, resulting products can be a form of effort to increase the income of fishermen's families so that the community of marine workers can be helped in economic problems.

Keyword : Family nutrition, Fish Processed, Fishermen, Oesapa Kupang

\section{PENDAHULUAN}

Wilayah perairan Indonesia adalah salah satu yang terbesar di dunia, luasnya mencapai 5.8 juta kilometer persegi. Wilayah perairan ini mempunyai nilai jual finansial utamanya hasil laut berupa ikan laut yang merupakan sumber protein dan nutrisi bagi kebutuhan manusia dan produk olahan lainnya. Pemanfataannya masih sangat kecil sampai saat ini, diperkirakan sekitar $58.5 \%$ dari pemanfaatan sumber daya ikan laut hanya mencapai 6.18 juta ton per tahun. Pemanfaatan ikan laut oleh warga masyarakat digunakan untuk sumber protein hewani dalam memenuhi kebutuhan nutrisi mereka, karena nilai nutrisi dan kandungan protein pada 
ikan sangat besar [1]. Protein sangat penting bagi tubuh untuk memperbaiki jaringan yang rusak dan membentuk jaringan baru [2].

Ikan segar, baik ikan laut dan air tawar, cepat terdegradasi oleh mikroorganisme sehingga rusak secara kimia dan enzimatik. Mikroorganisme seperti kuman, jamur, parasit dan adanya perubahan struktur kimia serta enzimatik pada ikan tangkapan nelayan mengubah protein ikan menjadi hasil degradasi peruraian kimiawi berupa perubahan bau dan ketengikan ikan. Oleh karenanya dibutuhkan teknologi pengolahan dan pengawetan ikan ataupun diversifikasi produk olahan ikan sehingga dapat mengawetkan ikan dalam waktu lama. Ikan kaleng ataupun ikan kering adalah bentuk olahan saat ini. Inovasi pengolahan ikan bertambah dengan bentuk abon ikan ataupun produk nugget ikan [3].

Ikan laut hasil tangkapan nelayan yang melimpah di provinsi Nusa Tenggara Timur menjadi salah satu hasil laut yang tiada habisnya. Utamanya bagi kelompok pekerja laut, ini bisa dikelola dan didayagunakan untuk menghasilkan barang bernilai jual besar sehingga dapat memberikan nilai tambah pendapatan dan peningkatan ekonomi, utamanya nelayan dan keluarganya. Setiap harinya nelayan menjual ikan hasil tangkapan baik secara tradisional maupun dengan penggunaan mesin dan teknologi, pada konsumen kedua, dalam ukuran dan volume besar dengan berbagai pilihan ragam ikan. Adakalanya ikan yang dipasarkan itu tidak terjual habis pada konsumen kedua, sehingga harus disimpan atau diawetkan dalam bentuk lain yang dapat bertahan waktu lama seperti dibuat menjadi ikan asin atau ikan yang dikeringkan. Cara lain yang ditempuh adalah mengolah ikan tangkapan pekerja laut itu menjadi produk lain yang dapat dijual dan tahan lama dalam bentuk diversifikasi produk ataupun dengan cara lain.

Dari wawancara dan tinjauan lapangan yang dilakukan dapat diidentifikasi berbagai persoalan yang menjadi permasalahan antara lain : (1) nelayan dengan penangkapan ikan berlebih; (2) pendapatan keluarga dari hasil penangkapan ikan kadang tidak mencukupi; (3) hasil penangkapan ikan berlebih hanya dikeringkan dengan cara tradisional; (4) belum adanya informasi dan pendampingan dalam pengolahan ikan dalam bentuk produk lain; (5) hiegienitas produksi, pengemasan dan pemasaran produk belum bagus; (6) belum dioptimalkannya sosialisasi gizi keluarga terutama protein ikan dalam bentuk sediaan lain yang memiliki nilai jual, dan (7) belum populernya informasi tentang pentingnya pengolahan ikan dalam bentuk produksi nugget ikan, dendeng ikan dan abon ikan dalam peningkatan gizi dan pendapatan masyarakat

Dari uraian di atas menunjukkan bahwa para pekerja hasil laut terutama nelayan dan pedagang ikan perlu diberikan informasi, sosialisasi, percontohan, dan pendampingan tentang perlakuan dan tahapan pada pengolahan ikan yang diolah menjadi produk lain seperti abon dan dendeng ikan. Menurut Sopandi dan Wardah [4], ikan segar hasil penangkapan akan mengalami perubahan kimiawi dan mikrobiologi karena adanya peruraian enzim akibat kerja mikroba, oksidasi pada gugus ikatan panjang karboksilat dan fase hidup mikrorganisme.

Manfaat dan keuntungan yang diperoleh dengan mengkonsumsi ikan antara lain : mampu memenuhi kebutuhan sepuluh asam lemak yang dibtuhkan oleh tubuh, mampu mengurangi dan menurunkan tekanan sistolik dan diastolik darah, mengurangi dan menurunkan kadar lemak dalam darah, menurunkan dan mengurangi bobot tubuh, menjadi nutrisi pertumbuhan sel otak dan kecerdasan, mampu menyehatkan mata, mampu mengurangi efek pengeriputan kulit, serta mengatasi penyakit metabolik dan tumor seperti PJK, arteroskelosis, kanker, dan tumor kandung kemih [5]. Berdasarkan penelitian Erawan dan Boer [6], kebutuhan mengkonsumsi ikan di Indonesia menunjukkan sekitar 40 kilogram perkapita per tahun. Jika dibandingkan dengan Malaysia, Indonesia masih kalah tingkat mengkonsumsi ikannya tahun 2010 sebesar 55.4 kilogram perkapita per tahun, sedangkan tahun 2015 mencapai 70 kilogram perkapita per tahun. Apalagi jika disejajarkan negara lain seperti Pyongyang, RRC, dan Jepang yang melebihi 140 kilogram perkapita per tahun.

Abon ikan adalah olahan produk ikan yang disukai oleh sebagian besar masyarakat Indonesia. Abon terbuat dari daging atau ikan, menjadi alternatif olahan makanan dan juga meningkatkan lama penyimpanan karena bentuknya sudah kering dengan kadar air kecil [7]. Produk abon ikan sebagai bentuk diversifikasi olahan ikan dari daging ikan mentah pilihan, diberi bumbu rempah pilihan, diolah dengan cara yang tepat sehingga menghasilkan produk yang berkualitas. Produk abon ikan memiliki peluang yang besar untuk dikembangkan menjadi produk unggulan tiap wilayah karena sangat diminati oleh masyarakat luas. Keunggulan abon menggunakan ikan marlin adalah abon ikan halus dan lembut, cita rasa gurih, enak, dan spesifik menggunakan rempah tradisional. Abon ikan marlin terbuat dari ikan marlin segar dan campuran bumbu yang diolah dari rempah rempah tradisional pilihan [8].

Nugget ikan dengan nuget daging sapi atau dengan nugget lainnya memiliki perbedaan. Nugget ikan adalah jenis nugget berbahan dasar daging ikan diiris kecil atau diuleg halus kemudian ditambahkan tepung manihot seperti kanji atau tapioka dengan menggunakan mesin pencampur adonan ataupun pencampuran manual lalu diberi bumbu-bumbu dan 
dan dilakukan pengukusan. Hasil kukusan adonan selanjutnya dicetak menjadi kotak atau persegi empat. Nugget biasanya dilapisi atau diselimuti dengan adonan encer campuran air, tepung pati, dan bumbu-bumbu penyedap dan selanjutnya dilapisi dengan tepung khamir, dan digoreng dalam minyak panas, atau bisa juga dibekukan dalam ruang pendingin (freezer). Yang membedakan nugget ikan dengan nugget ayam atau nugget sapi adalah bentuk serat yang elastis dan kenyal. Bentuk serat nugget ikan dipengaruhi oleh banyak determinan, yaitu : daging ikan yang digunakan, segar atau tidak ikan yang digunakan, faktor $\mathrm{pH}$ dan kandungan air pada daging ikan, perlakuan pada tahap pembersihan dengan air, lama penyimpanan atau pengawetan ikan, kondisi suhu dan waktu penggorengan dengan pemanasan, jenis dan konsentrasi bumbu penyedap rasa sebagai bahan tambahan yang digunakan. Kualitas atau mutu olahan nugget ikan yang baik adalah ketika bentuk serat nugget ikan kenyal, rasa gurih dan renyah. Nugget ikan lezat hendaknya menggunakan volume tapioka paling banyak sekitar 15-30\% dari isi nugget. Lebih baik jika tapioka yang diberikan sejumlah $10 \%$ berat bahan dasar nugget. Biasanya nugget di pasaran menggunakan tepung nugget mencapai $30-40 \%$ dari berat daging [9].

Makanan adalah kebutuhan pokok manusia. Yang perlu diperhatikan adalah ketercukupan gizi dalam makanan yang dikonsumsi. Banyak kasus terjadi, terutama pada balita dan anak pra sekolah, maupun usia belajar di sekolah, mengalami kekurangan pemberian makanan bernutrisi makro maupun nutrisi mikro [10]. Menurut Kresnasari dkk. [11], Indonesia merupakan negara dengan wilayah laut luas dengan kekayaan hasil laut yang jumlahnya melimpah, tetapi persentase makanan dengan komposisi ikan di Indonesia masih rendah. Salah satu tindakan yang dilakukan terhadap hal ini adalah dengan menumbuhkan keinginan dan kegemaran makan ikan pada peserta didik [11]. Nutrisi makro, terutama asam amino dan nutrisi mikro berupa vitamin dan mineral, yang terkandung dalam ikan mampu mencegah penyakit degenaratif. Ikan memiliki nutrisi mikro yang dikenal sebagai omega tiga yang bermanfaat mengurangi kadar lemak darah dalam darah.

Berdasarkan fenomena di atas perlu dilakukan pengabdian masyarakat berupa pemberdayaan masyarakat wilayah pesisir pantai kupang. Fakultas Kesehatan Masyarakat Universitas Nusa Cendana dalam rangka meningkatkan nilai tambah dan makna Perguruan Tinggi, melakukan program kemitraan masyarakat dalam bentuk aplikasi teknologi tepat guna hasil pengembangan ilmu pengetahuan dan seni (ipteks) [12]. Menurut Muntasir dkk. [13], Universitas Nusa
Cendana harus mampu menjadi pelopor dalam pengentasan masalah di provinsi Nusa Tengara Timur dan lingkungan sekitarnya baik pada bidang sosial, budaya, ilmu pengetahuan dan lainnya. Universitas Nusa Cendana sebagai lembaga ilmiah terbesar di Nusa Tenggara Timur memiliki akademisi dan karya ilmiah yang bisa diterapkan dan dikembangkan guna meningkatkan kesejahteraan hidup masyarakat dan memberi nilai ekonomis [14].

Penerapan ilmu pengetahun, teknologi dan seni bagi masyarakat dalam bentuk sosialisasi dan penerapan teknologi tepat guna, mudah dikerjakan dan dapat dilakukan. Salah satu cara yang dilakukan adalah dengan pengabdian masyarakat dalam bentuk program kemitraan masyarakat. Dalam hal ini disusun program kemitraan masyarakat yang berlokasi di Kecamatan Kelapa Lima Kelurahan Oesapa dimana terdapat perkampungan nelayan Oesapa. Adapun permasalahan yang dihadapi antara lain :

1. Persoalan Nelayan dengan penangkapan ikan yang berlebih

2. Pendapatan keluarga dari hasil penangkapan ikan kadang tidak mencukupi

3. Hasil penangkapan ikan berlebih hanya dikeringkan dengan cara tradisional

4. Belum adanya informasi dan pendampingan dalam pengolahan ikan dalam bentuk produk lain dan Hiegienitas produksi, pengemasan dan Pemasaran produk

5. Belum dioptimalkannya sosialisasi gizi keluarga terutama protein ikan dalam bentuk sediaan lain yang memiliki nilai jual

6. Pentingnya pengolahan ikan dalam bentuk produksi Nugget Ikan dalam peningkatan gizi dan pedapatan masyarakat

7. Pentingnya pengolahan ikan dalam bentuk produksi Dendeng ikan dalam peningkatan gizi dan pedapatan masyarakat dan

8. Pentingnya pengolahan ikan dalam bentuk produksi Abon Ikan dalam peningkatan gizi dan pedapatan masyarakat

\section{METODE PELAKSANAAN}

Metode penerapan program kemitraan masyarakat dilakukan dengan langkah-langkah kegiatan yang dimodifikasi dari Muntasir, Purnawan, \& Sahdan [15], dan mengikuti hasil pengabdian masyarakat Weraman, Muntasir, Jutomo, \& Harijono [16]. Metode program kemitraan masyarakat ini juga didasari dari pengabdian masyarakat yang telah dilakukan dan mengikuti metode yang dimodifikasi dari $[17,18]$, dalam bentuk "Pendidikan dan Pelayanan Kepada Masyarakat" dengan melakukan aktivitas kegiatan yang direncanakan bertahap untuk dapat 
memudahkan pelaksanaan dan evaluasinya. Tahapan-tahapan yang dimaksud sebagai berikut :

1. Melakukan kegiatan ceramah, sosialisasi, penyuluhan tentang gizi keluarga dan pemenuhan protein untuk keluarga

2. Melakukan pelatihan dan pendampingan pengolahan nugget ikan.

3. Melakukan pelatihan dan pendampingan pengolahan dendeng ikan

4. Melakukan pelatihan dan pendampingan tentang pengolahan abon ikan.

5. Mengajak dan memotivasi masyarakat untuk meningkatkan gizi keluarga dengan pengolahan ikan dalam bentuk dan produk lain yang bernilai gizi dan mempunyai nilai jual yang dapat dipasarkan

6. Melatih masyarakat untuk menggunakan teknologi tepat guna pengolahan dan diversifikasi olahan ikan dengan peralatan sederhana dan hiegienis.

7. Memanfaatkan hasil tangkapan ikan nelayan untuk produksi dan diversifikasi olahan ikan yang mempunyai manfaat bagi masyarakat untuk peningkatan gizi dan kesehatan dan memilki nilai jual yang tinggi

8. Melakukan sosialisasi pemasaran dan menjelaskan manfaat ekonomi dalam bentuk memberikan alternatif usaha baru khususnya dalam pembuatan produk nuget ikan, dendengan dan abon ikan untuk mendapatkan penghasilan tambahan bagi ibu rumah tangga nelayan.

9. Menyedianya alat produksi pengolahan nugget ikan, pengolahan dendeng ikan, pengolahan abon ikan

10. Melaksanakan pendampingan kegiatan pengolahan nugget ikan, pengolahan dendeng ikan, pengolahan abon ikan.

11. Melaksanakan monitoring tiap kegiatan pelatihan dan evaluasi pra dan post pelatihan pengolahan nugget ikan, pengolahan dendeng ikan, pengolahan abon ikan

12. Melaksanakan evaluasi akhir kegiatan

13. Melakukan kerjasama antara mitra usaha dan tim pelaksana kegiatan dalam bentuk keberlanjutan kegiatan.

\section{PELAKSANAAN KEGIATAN}

Program kemitraan masyarakat ini telah dilakukan atas Anggaran Universitas Nusa Cendana sesuai dengan Surat Perjanjian Pelaksanaan Program Kemitraan Masyarakat Pada LP2M Universitas Nusa Cendana dengan Nomor 116/UN15.19/PM/2020 Tanggal : 5 Mei 2020. Kegiatan dilakukan berurutan sesuai tahapan yang direncanakan. Sejauh ini telah dilakukan survei ke mitra nelayan dan masyarakat pesisir terutama ibu rumah tangga nelayan untuk menentukan jumlah dan target peserta kegiatan. Kegiatan lainnya sedang dan akan dilakukan, dan direncanakan selesai pada akhir Oktober 2020. Dari hasil survei awal didapatkan sasaran utama kegiatan dari masyarakat nelayan pesisir Oesapa yaitu keluarga nelayan anggota jamaah masjid Al Hidayah, namun tidak menutup kemungkinan ada masyarakat nelayan Oesapa lainnya untuk mengikuti jika bisa dam mau. Jumlah khalayak berkisar antara 20-40 keluarga nelayan, yaitu ibu rumah tangga nelayan dan masyarakat yang berada di lokasi kegiatan ini.

Adapun evaluasi pelaksanaan program dan keberlanjutan yang akan dilaksanakan adalah :

1. Pelaksanaan dan evaluasi alat meliputi :

a. Diskusi Tim Pelaksana dengan Mitra terhadap alat yang telah diserahkan dan masalah, kelebihan dan kekurangan alat pada peningkatan produksi.

b. Evaluasi Mitra terhadap Penerapan yang telah diajarkan.

2. Pemantauan Tim Internal Lembaga Pengabdian Masyarakat di lokasi Mitra sesuai kontrak.

3. Pemantauan dan Evaluasi Tim Pelaksana Program dari sponsor bantuan program yang disampaikan kepada Mitra, berupa pembuatan laporan akhir kegiatan oleh Tim Pelaksana dan Seminar Hasil Kegiatan oleh Tim Pelaksana di LPM Undana yang ditentukan secara tentatif.

\section{Pendampingan dan Keberlanjutan Pasca \\ Pelaksanaan Kegiatan}

Adapun pendampingan pasca pelaksanaan program dilakukan setelah kegiatan dilaksanakan untuk memastikan keberlanjutan program yang disampaikan. Kegiatan ini direncanakan meliputi :

a. Diskusi Tim Pelaksana dengan Mitra tentang masalah, kelebihan dan kekurangan alat yang telah diserahkan dalam pengolahan ikan.

b. Evaluasi Mitra terhadap penerapan teknologi yang telah diberikan. 


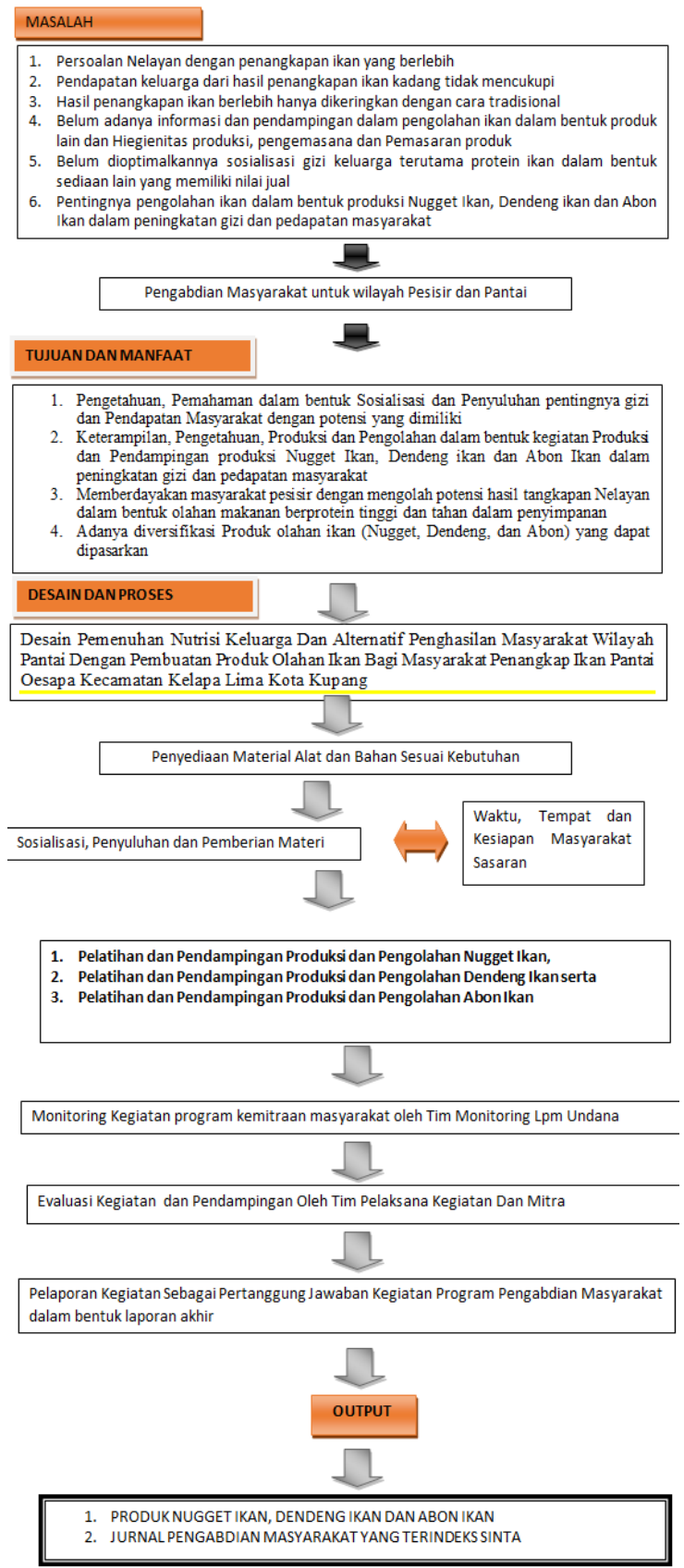

Gambar 1 Alur Pikir Kegiatan

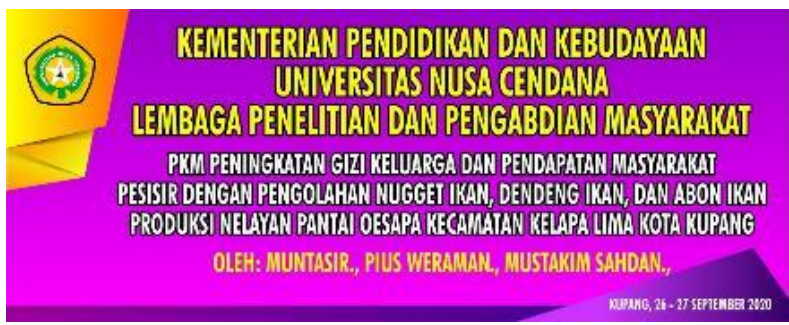

Gambar 2. Spanduk Kegiatan

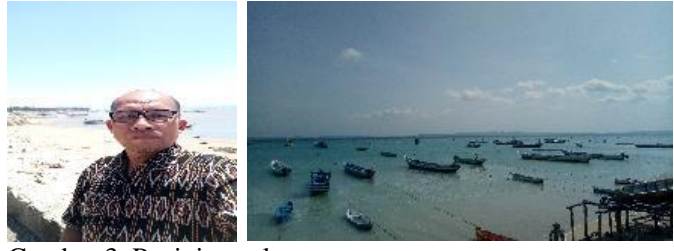

Gambar 3. Peninjauan lapangan
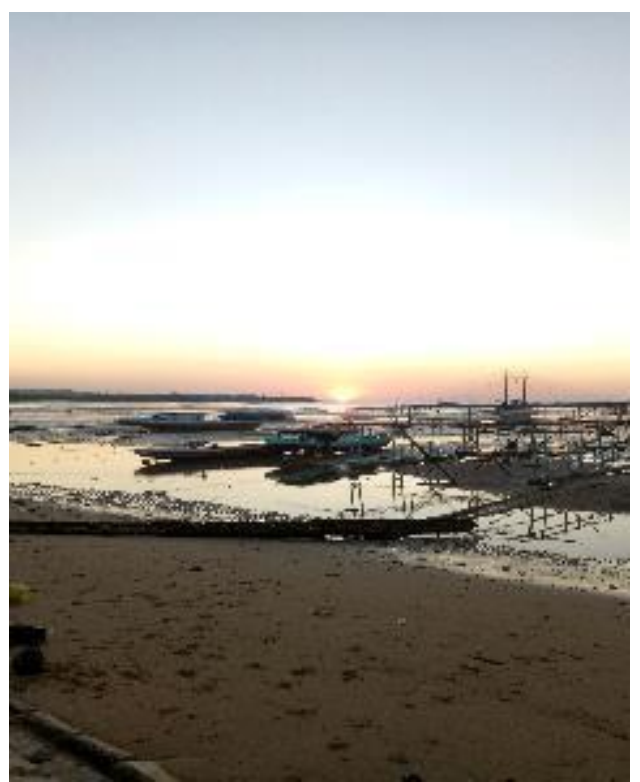

Gambar 4. Kondisi Pantai Oesapa yang menjadi lokasi kegiatan

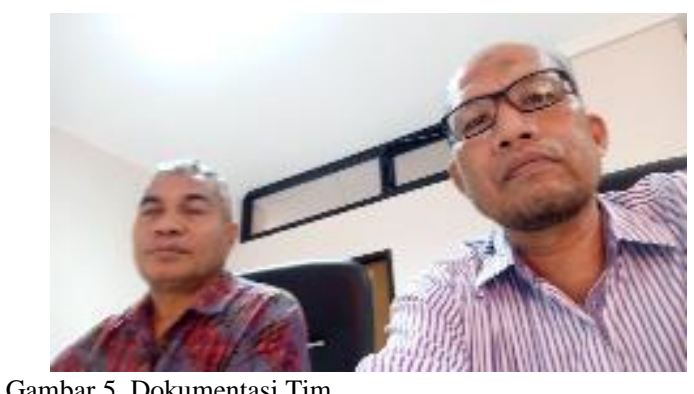

\section{PENUTUP}

Program Kemitraan Masyarakat ini dirancang untuk diterapkan di masyarakat dengan pendanaan DIPA Undana 2020, bertujuan mengembangkan usaha kelompok masyarakat agar mandiri dan meningkatkan nilai tambah pendapatan serta meningkatkan keterampilan mitra dalam memanfaatkan teknologi.

Kegiatan ini juga menjadi alternatif pemenuhan gizi keluarga terutama protein hewani yang menarik bagi ibu rumah tangga dan keluarga nelayan. Juga diharapkan meningkatkan nilai tambah produk, pengetahuan, penggunaan dan pengolahan sumber protein hewani yang dapat meningkatkan nilai gizi, tekstur, olahan dan produk. Sebagai bentuk penerapan teknologi ipteks Perguruan Tinggi, produk yang dihasilkan bisa menjadi salah satu bentuk usaha untuk meningkatkan pendapatan keluarga nelayan 
sehingga masyarakat dapat terbantukan dalam persoalan ekonomi.

Nilai tambah kegiatan yang dirancang dapat ditinjau dari :

1. adanya transformasi ilmu dan pengetahuan, pemahaman dalam bentuk sosialisasi dan penyuluhan pentingnya gizi dan pendapatan masyarakat dengan potensi yang dimiliki

2. peningkatan keterampilan, dan pengetahuan mitra dalam hal produksi dan pengolahan ikan (nugget ikan, dendeng ikan dan abon ikan)

3. memberdayakan masyarakat pesisir dengan menambah potensi hasil tangkapan nelayan dalam bentuk olahan makanan berprotein tinggi dan tahan dalam penyimpanan

4. adanya diversifikasi produk olahan ikan (nugget, dendeng dan abon) yang dapat dipasarkan

5. adanya kelompok masyarakat terutama keluarga nelayan kelompok ibu-ibu majelis taklim yang mampu mengolah dan memproduksi olahan ikan (nugget, dendeng dan abon) yang dapat dikonsumsi untuk peningkatan gizi keluarga, dapat diproduksi massal, dan dipasarkan

6. capaian akhir program kemitraan masyarakat berupa publikasi ilmiah pada jurnal pengabdian masyarakat ber-ISSN dan publikasi pada media masa online (koran online)

Disarankan untuk membuat alat pemasakan ikan dalam volume besar dan mesin kemasan vakum yang bisa dipakai oleh mitra dan kelompok binaan. Selain itu perlu promosi olahan ikan (nugget ikan, dendeng ikan dan abon ikan) yang menarik sebagai produk unggulan khas NTT. Juga disarankan penganekaragaman kemasan atau packing olahan ikan yang menarik, kreatif dan berharga murah yang bisa dipasarkan.

\section{PENGHARGAAN}

Penghargaan kami sampaikan kepada Pimpinan Universitas Nusa Cendana dan ketua Lembaga Penelitian dan Pengabdian Masyarakat Universitas Nusa Cendana (LP2M Undana) yang telah memberikan Hibah Pengabdian Masyarakat tahun 2020 terseleksi, kepada Pimpinan Fakultas Kesehatan Masyarakat dan Universitas Nusa Cendana yang telah memberikan kesempatan bersaing untuk mendapatkan hibah kompetisi pengabdian masyarakat, dan Mitra Nelayan dan Keluarga Nelayan yang tergabung dalam kelompok pengajian Masjid Al Hidayah Oesapa Kota kupang.

\section{DAFTAR PUSTAKA}

[1] Dwi Andayani. 2020. Buka Raker BPPT, Ma'ruf Sebut RI Kurang Penguasan Iptek dalam Inovasi, https://news.detik.com/ berita/d-4911743/buka-raker-bppt-maruf-sebutri-kurang-penguasan-iptek-dalam-inovasi? $\mathrm{ga}=2.131247500 .2081810285 .1604205659$ 1059167617.1602648124. Akses September 2020

[2] Almatsier, S. Soetardjo, S. Soekantri, M. 2011. Gizi Seimbang dalam Daur Kehidupan. Jakarta. PT. Gramedia Pustaka Utama.

[3] Heny Kusumayanti, Widi Astuti, RTD. Wisnu Broto. 2011. Inovasi Pembuatan Abon Ikan Sebagai Salah Satu Teknologi Pengawetan Ikan. Gema Teknologi Vol. 16 No. 3.

[4] Annytha Detha, Nemay Ndaong, Nancy Foeh, Putri Pandarangga. 2018, Teknik Pengolahan Dendeng Ikan Gula Nira Lontar Pada Pedagang Ikan Di Kota Kupang, NTT. Jurnal Pengabdian Masyarakat Peternakan ISSN: 2502-5392 Vol. 3 No. 1. Hal. 1-10

[5] WHO. 2003. Diet, Nutrition, and The Prevention of Chronic Disease, Technical Report Series 916 of a Joint FAO/WHO Expert Consultation, WHO, Genewa.

[6] Erawan, E Dan K.M. Boer. 2018. Analisis Efektivitas Sosialisasi Program Gemarikan Oleh Bidang Pengolahan Dan Pemasaran Hasil Perikanan (P2HP) Di Dinas Kelautan Dan Perikanan Provinsi Kalimantan Timur di kota Samarinda. Jurnal Ilmu komunikasi. Vol 6 (2) : 125-136. ISSN 2502-597X

[7] Lisdiana, 1997. Membuat Aneka Abon. Yogyakarta; Penerbit Kanisius

[8] Yolanda Cicilia Br. Karo, Rodiana Nopianti, Shanti Dwita Lestari. 2017, Pengaruh Variasi Suhu Terhadap Mutu Abon Ikan Ekonomis Rendah Selama Penyimpanan. FishtecH Jurnal Teknologi Hasil Perikanan Vol. 6, No.1: 80-91

[9] Tim KKP. Modul Nugget Ikan

[10] Ni Ketut Etty Suwitari, M.Si.. Ni Made Yudiastari., Luh Suariani, M.Si. 2018, PKM Pembuatan Aneka Nugget di KWT Teratai 8 dan 9 Dusun Segah Desa Asahduren Pekutatan Jembrana, WICAKSANA, Jurnal Lingkungan \& Pembangunan, September 
2018. Vol. 2 No. 2 : Hal. 9-17 ISSN: $2597-$ 7555 E-ISSN: 2598-987 https://ejournal. warmadewa.ac.id/index.php/wicaksana.

[11] Dewi Kresnasari, Dian Mustikasari, dan Any Kurniawati. 2019, Pembuatan Nugget Ikan (Fish Nugget) Sebagai Salah Satu Usaha Deferensiasi Pengolahan Ikan Di Sekolah Alam Banyu Belik. Cendekia : Jurnal Pengabdian Masyarakat Vol. 1 No. 2 Bulan Desember 2019 halaman 42-50. http://ejournal.uniska-kediri.ac.id/index.php /CENDEKIA 42-50. eISSN : 2685-130X. pISSN : 2684-9003. doi:http://dx.doi.org/ 10.32503/Cendekia.v1i2.589

[12] Muntasir, Sri Prilmayanti A. Aplikasi Teknologi Tepat Guna pada Pembuatan Kue Donat, Kue Roti dan Roti Goreng pada Mitra Usaha Roti Sari dan Dian Jaya Kota Kupang. Jati Emas (Jurnal Aplikasi Teknik dan Pengabdian Masyarakat) Vol.1 No. 2 hal. 8994. - e. ISSN: 2550-0821

[13] Muntasir., Lewi Jutomo., Ali Warsito., Hyronymus Djati., Eddy H. Ismail., Caro David Hadel Edon. 2019, Peningkatan Kualitas, Promosi dan Diversifikasi Pemasaran Produksi Alat Musik Sasando Tradisional dan Elektrik sebagai Upaya Melestarikan Budaya Lokal Nusa Tenggara Timur. Jati Emas (Jurnal Aplikasi Teknik dan Pengabdian Masyarakat) Vol. 3 No. 1 hal. 1-9. e. ISSN: 2550-0821

[14] Profile Universitas Nusa Cendana, http://undana.ac.id
[15] Muntasir., Sigit Purnawan., Mustakim Sahdan. 2018, Penerapan Alat Peniris Serbaguna Model Silinder Sistem Sentrifuse Untuk Meningkatkan Mutu Dan Higienis Produk Kerupuk Jagung Kelimutu Sikumana Kota Kupang. Jati Emas (Jurnal Aplikasi Teknik dan Pengabdian Masyarakat) Vol. 2 No. 1. Hal. 50-55. e. ISSN: 2550-082

[16] Pius Weraman, Muntasir, Lewi Jutomo, Harijono. 2019. Alat Pengering Model Rak Bersusun Sistem Kolektor Plat Datar Sumber Energi Panas Matahari Untuk Meningkatkan Mutu Dan Higienis Produk Industri Kecil Kerupuk Dan Jagung Marning Usaha Sima Indah Kupang. Jati Emas (Jurnal Aplikasi Teknik dan Pengabdian Masyarakat) Vol. 3 No. 1 hal. 88-94. e. ISSN: 2550-0821

[17] Muntasir dan Pius Weraman. 2018,Pengurangan Kadar Minyak Pada Abon Ikan Produksi Savitri Dan Tiaras Dengan Penerapan Alat Peniris Serbaguna Di Kota Kupang. Jati Emas (Jurnal Aplikasi Teknik dan Pengabdian Masyarakat) Vol. 2 No. 2 Hal. 20-27. e. ISSN: 2550-0821

[18] Mustakim Sahdan, Sigit Purnawan, Muntasir, Hari Rarindo., Sri Prilmayanti 2018, Penerapan Mesin Pengaduk Adonan dan Etalase Produk Pada Usaha Pembuatan Kue Ulenan dan Donat di Pasar Tradisional Penfui Kota Kupang. Jati Emas (Jurnal Aplikasi Teknik dan Pengabdian Masyarakat) Vol. 2 No. 2 hal. 28-34. E. ISSN: 2550-0821 
Jati Emas (Jurnal Aplikasi Teknik dan Pengabdian Masyarakat)

Vol. 4 No. 2 Oktober 2020 - e. ISSN: 2550-0821 